\title{
Strength Assessment of Egg Shell Powder Cement Concrete
}

\author{
R. Venkata Krishnaiah, P. Dayakar, K. Venkatraman
}

\begin{abstract}
The investigation of solidarity conduct of cement, having incomplete supplanting of concrete with egg shell powder (ESP) as replacement material in M20 grade for which an exploratory examination is to be completed and the impact of this replacement material in various proportions on strength quality attributes is considered. Presently aftereffect of this, the investigation demonstrates the supplanting of $5 \%$ of binder with this replacement material accomplishes the most extreme strength quality. Best ideal level of supplanting of egg shell powder with binder is nearly $5 \%$ of the concrete for cubes and it likewise limit the expense of development with the utilization of egg shell powder, which is accessible unreservedly or efficiently.
\end{abstract}

Keywords: egg shell powder, M20

\section{INTRODUCTION}

\section{A. General}

In reinforced concrete structures, flexural failure is one of the main threats being faced. Many methods were adopted to increase the strength and flexural behaviour of the structure. Since plain concrete possesses very low tensile strength, limited ductility, and little resistance to cracking. Internal micro-cracks are present in the concrete and these micro-cracks are caused due to low tensile strength. By using fibre reinforced concrete the toughness of the structure.

Nowadays, fibres are produced from different materials such as steel, glass, carbon, and synthetic material. Each one of these fibres has its specific benefits. However, steel fibre is the most common one. It has been reported that the first experimental trail to improve concrete characteristics using discontinues steel reinforcing elements, such as nail segment, was done in 1910. However, it was not until 1963 when major experiments were done to improve concrete characteristics using real steel fibres. A typical length of steel fibres ranges from 0.25 to 2.5 in ( 6 to $64 \mathrm{~mm}$ ), and its diameter ranges from 0.02 to 0.04 in $(0.5$ to $1.0 \mathrm{~mm})$. steel fibres are produced in

Revised Manuscript Received on October 22, 2019.

R. Venkata Krishnaiah,, Associate Professor, Department Of Civil Engineering,,Bharath Institution of Higher Education And Research,TamilNadu, India Email venkatapec@gmail.com

P. Dayakar, Associate Professor,,Department Of Civil Engineering,,Bharath Institution Of Higher Education And Research,TamilNadu, India .Email: dayakarpitti@yahoo.co.in

K. Venkatraman, Asistant Professor, Department Of Civil Engineering,,Bharath Institution of Higher Education And Research,TamilNadu, India Email: venkatraman.civil@bharathuniv.ac.in different form as shown in figure 1.1. This type of fibre is available commercially in tensile strength up to 300ksi (2068 $\mathrm{MPa}$ ).

Concrete is weak in tension and micro cracks are developed in conventional reinforced concrete. To avoid the propagation of micro cracks in RCC, fibres are added as secondary reinforcement and it also improves the mechanical properties of concrete. The influences of hooked end fibres in conventional RCC will be studied in this project. The beams with fibres and without fibres are to be tested under monotonic loading, to study the behaviour of SFRC beams in the ultimate and post ultimate regions. Now a days natural disaster such as earthquake, wind force etc. plays an important role in the construction industry. So buildings and other construction work should be designed in good manner, which resist higher loads and seismic forces. Ductility and energy absorption capacity are the main requirement of the earthquake resistant structure. Fibre reinforced concrete posses high strength, improved ductility and enhancing energy absorption capacity. So the study on the flexural behaviour of beams.[1]-[5]

\section{REVIEW OF LITERATURE}

Amu et al (2012) expressed that use of egg shell powder on lateritic soil acquiring is a superior compliment for egg shell as a helpful in inhancement to interstate asphaltprojects. There is an improment in adjustment by including 2-10 percent of normal seasalts with ideal ESP. Finally outcomes demonstrated that the expansion of normal salt improves dry thickness and California Bearing Ratio estimations of ESP balanced out the grounds.

Okonkwo et al (2016) inferred that the ESP powder can be utilized as an substitute to the binder which brought about greater UCC of delicated earth soils. The addition of cement of 6 and $8 \%$ included with the ESP of $0-10$ percent at 2 percent interims shows increment in thirty five percent of UCC strength. At last they found that dirt concrete egg shell blend can be utilized for thruway asphalts.[6]-[10]

\section{EXPERIMENTAL STUDY}

Preliminary tests are carried out as per IS standard for fine aggregate (sand) and coarse

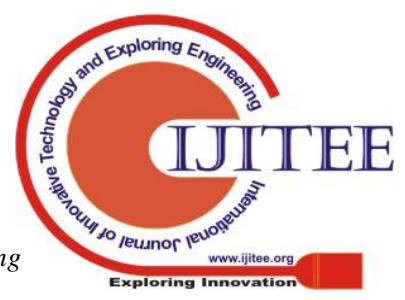


aggregate. For sands, specific gravity, fineness modulus are found out and for coarse aggregates, specific gravity, impact value, crushing value and Los Angeles were conducted and the results are tabulated in below.

Testing of hardness of concrete is carried out as per IS standards to estimate the properties of hardened cubes. Cube compressive strength test on was conducted.[11]-[15]

Tests on cement 43 grade (Physical)

\begin{tabular}{|l|c|c|}
\hline Sl.no & Properties & Test results \\
\hline 1. & Specific gravity & 3.15 \\
\hline 2. & Fineness & $7.33 \%$ \\
\hline 3. & Normal & $37 \%$ \\
\hline 4. & Initial setting time & $48 \mathrm{~min}$ \\
\hline
\end{tabular}

Tests on sand

\begin{tabular}{|c|c|c|}
\hline Sl.no & Type of Test & Result \\
\hline 1. & Specific gravity & 2.55 \\
\hline 2. & Fineness Modulus & 3.25 \\
\hline
\end{tabular}

\section{Tests on ESP}

\begin{tabular}{|l|c|c|}
\hline Sl.no & Properties & Test results \\
\hline 1. & Specific gravity & 3.0 \\
\hline 2. & Colour & White \\
\hline 3. & Form & Powder \\
\hline
\end{tabular}

\section{DESIGN MIX}

\section{Data and Regulations:}

Concrete : M Twenty

Type of binder: Ordinary Portland

Type of mineral Admixture : NIL

Max. size of aggregate $\quad: 20 \mathrm{~mm}$

Min. binder content $\quad: 240 \mathrm{~kg} / \mathrm{m}^{3}$

Max. Liquid -binder ratio : 0.50

Workability in mm of slump : $: 25-50 \mathrm{~mm}$

Environment condition : moderate

Type of concrete : : Non - Pumping

Supervision : Good

Aggregate used : Crushed and angular type aggregate

\section{A) DATA AND PROPERTIES OF MATERIALS}
a) Binder used
: Ordinary Portland Cement

(Type 43)

b) Specific gravity of binder : 3.15

c) Specific gravity of
1) Aggregate coarse
: 2.71
2) Sand
: 2.55

d) Water inception
1) Aggregate coarse
: $0.6 \%$
2) Sand
: $1.0 \%$

e) Moisture on surface
1) Aggregate coarse
: Nil
2) Sand
$: 1 \%$

f) Partical size analysis
1) Sand
: Second zone

B) REQUIRED STRENGTH FOR MIX Required Mean Strength,

$$
\begin{aligned}
\mathrm{f}_{\text {ck }}^{\prime} & =\mathrm{f}_{\text {ck }}+1.65 s \\
& =20+1.65 \mathrm{x} 4 \\
& =26.60 \mathrm{~N} / \mathrm{mm}^{2}
\end{aligned}
$$

where

$\mathrm{f}_{\text {ck }}^{\prime}=$ Required average compre. strength at a curing of 28 days,

$\mathrm{f}_{\mathrm{ck}}=$ characteristic compre. strength at a curing of 28 days, and

$$
s=\text { standard deviation. }
$$

Standard deviation taken from IS code table,

$$
s=4
$$

\section{C) $\mathrm{H}_{2} \mathrm{O}$ - BINDER RATIO}

From Indian standards, it was taken that maximum liquid/ binder ratio $=0.50$

Based on experience, adopt $\mathrm{H}_{2} \mathrm{O}$ - binder ratio as 0.45 .

$0.45<0.50$ hence O.K.

\section{D) QUANTITY OF $\mathrm{H}_{2} \mathrm{O}$}

From Indian standards, maximum quantity $\mathrm{H}_{2} \mathrm{O}$ for $20 \mathrm{~mm}$ aggregate $=186$ litres

Selecting the quantity of $\mathrm{H}_{2} \mathrm{O}$ for $20 \mathrm{~mm}$ aggregate $=186$ litres

\section{E) CALCULATION OF QUANTITY OF BINDER}

$$
\begin{aligned}
\mathrm{H}_{2} \mathrm{O} \text { - binder ratio } & =0.45 \\
\text { Binder quantity } & =186 / 0.45=413.33 \mathrm{~kg} / \mathrm{m}^{3}
\end{aligned}
$$

From Indian Standards, least quantity of binder for 'moderate' condition $=240 \mathrm{~kg} / \mathrm{cum}$

$$
\begin{gathered}
413.33 \mathrm{~kg} / \mathrm{cum}>240 \mathrm{~kg} / \mathrm{cum} \\
\text { Its OK. }
\end{gathered}
$$

\section{F) Quantity Of Coarser And Fine Aggregates}

From Indian Standards, Quantity of coarser totals relating to twenty $\mathrm{mm}$ size total and for sand related to second zone for $\mathrm{H}_{2} \mathrm{O}-$ Binder Ratio of $0.5=0.62$. 
For this, $\mathrm{H}_{2} \mathrm{O}-$ Binder Ratio is 0.45 . In this manner, amount of coarser fraction used to be expanded to diminish the amount of sand. As the $\mathrm{H}_{2} \mathrm{O}-$ Binder proportion is lower by 0.05 , extent amount total is expanded by 0.01 . The rectified extent amount of bigger total for the $\mathrm{H}_{2} \mathrm{O}$ - binder proportion of $0.45=0.62$.

Therefore, quantity of sand $=1-0.62=0.38$

\section{G) CONCRETE DESIGN CALCULATIONS}

The proportion of calculations for 1 cum of mix:

a) Volume of mixture $\quad=1 \mathrm{cum}$

b) Volume of binder $=($ mass of binder $) /($ specific gravity of

binder) $\times 0.001$

$=$

$(413.33) /(3.15) \times 0.001=0.131 \mathrm{cum}$

c) Volume of $\mathrm{H}_{2} \mathrm{O}=$ (mass of $\left.\mathrm{H}_{2} \mathrm{O}\right) /\left(\right.$ of $\left.\mathrm{H}_{2} \mathrm{O}\right) \times 0.001$

$=(186) /(1) \times 0.001=0.186 \mathrm{cum}$

d) Qty. of aggre. coarser $=[\mathrm{a}-(\mathrm{b}+\mathrm{c})]$

$$
=[1-(0.131+0.186)]
$$$$
=0.683 \mathrm{cum}
$$

e) Weight of coarse aggre. $=\mathrm{d} \times$ Vol. of aggre. coarser $\times \mathrm{G}$ of aggre. coarser $\times 1000$

$$
\begin{aligned}
& =0.683 \times 0.62 \times 2.71 \times 1000 \\
& =1147.57 \mathrm{Kg}
\end{aligned}
$$

f) Sand Weight $\quad=d \times$ Vol. of sand $\times$ G of sand $\times 1000$

$$
\begin{aligned}
& =0.638 \times 0.38 \times 2.55 \times 1000 \\
& =661.82 \mathrm{~kg}
\end{aligned}
$$

Mix Proportion For M-20 Concrete

\begin{tabular}{|c|c|c|c|}
\hline Water & Cement & $\begin{array}{c}\text { Fine } \\
\text { Aggregate }\end{array}$ & $\begin{array}{c}\text { Coarse } \\
\text { Aggregate }\end{array}$ \\
\hline 186 lit & $\begin{array}{c}413.33 \\
\mathrm{~kg}\end{array}$ & $661.82 \mathrm{~kg}$ & $1147.57 \mathrm{~kg}$ \\
\hline 0.45 & 1 & 1.60 & 2.78 \\
\hline
\end{tabular}

\section{CALCULATION OF QUANTITITIES FOR $50 \mathrm{~kg}$ OF CEMENT}

The proportion resulted that 1:1.60:2.78. For $50 \mathrm{~kg}$ of cement, the quantities of various elements are as follows:

a) Binder $=50 \mathrm{~kg}$

b) Fine aggregate $=80.225 \mathrm{~kg}$

c) Coarse aggregate $=139 \mathrm{~kg}$

d) $\mathrm{H}_{2} \mathrm{O}$

1) For liquid- binder ratio of 0.45 volume of water $=22.5$ litres

2) Volume of $\mathrm{H}_{2} \mathrm{O}$ to be added by considering inception in coarse aggregate, at 0.90 parts by mass $=(+) 0.203$

3) Volume of $\mathrm{H}_{2} \mathrm{O}$ to be less for bulking of sand, at $1.0 \%$

$$
=(-) 0.225
$$

4) Real volume of $\mathrm{H}_{2} \mathrm{O}$ to be mixed totally

$$
=22.5+0.203-0.225=23 \text { lit. }
$$

e) Real proportion of fine aggregate required after considering the free moisture

$$
=80+0.225
$$$$
=80.225 \mathrm{~kg}
$$

f) Actual quantity of coarse aggregate required $=139-$ 0.203 $=138.80 \mathrm{~kg}$

Therefore, the required actual quantities of different elements are as follows

$$
\begin{array}{ll}
\mathrm{H}_{2} \mathrm{O} & =23 \text { lit } \\
\text { Binder } & =50 \text { kilogram } \\
\text { Sand } & =80.225 \mathrm{~kg}
\end{array}
$$

Coarser aggre. $=138.80 \mathrm{~kg}$

Compression stress after 7 days of curing

\begin{tabular}{|c|c|c|c|c|}
\hline Grade & $\begin{array}{c}\% \text { of } \\
\text { replacem } \\
\text { ent }\end{array}$ & $\begin{array}{c}\text { Sample } \\
1\end{array}$ & Sample 2 & $\begin{array}{c}\text { Avg.compressi } \\
\text { ve strength for } \\
7 \text { days } \\
\left(\mathrm{N} / \mathrm{mm}^{2}\right)\end{array}$ \\
\hline M20 & $0 \%$ & 10.10 & 8.35 & 9.225 \\
\hline & $5 \%$ & 8.65 & 9.35 & 9.00 \\
\hline & $10 \%$ & 7.55 & 9.16 & 8.35 \\
\hline & $15 \%$ & 6.35 & 7.25 & 6.9 \\
\hline
\end{tabular}

Graph presentation of Compression Stress after 7 days of curing

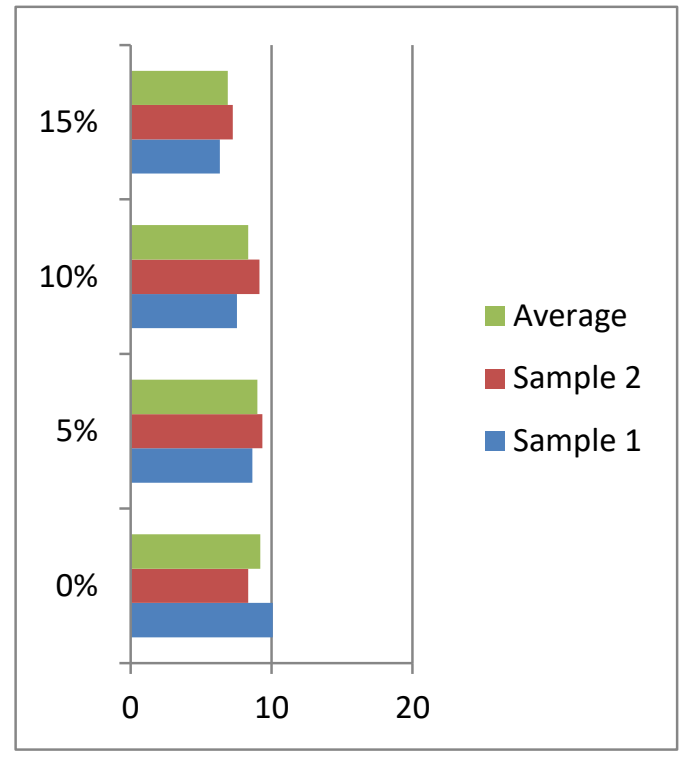

\section{RESULTS}

\section{A. Strength Tests}

Concrete was poured in cubes and compacted well. Then casted in correct shape and after twenty four hours removing the cubes from moulds. 
The load bearing surfaces of the cubes was make smoothened. At that point, following 7 days curing, the cubes are dried and placed in loading platform of UTM. [16]-[20]

The Uniaxial compression of solid cube is the most extreme pressure that the cube can withstand under a gradually applied load without break. Compression strength of cube is estimated as by dividing the maximum burden by its load bearing area.

\section{Compression stress after 28 days of curing}

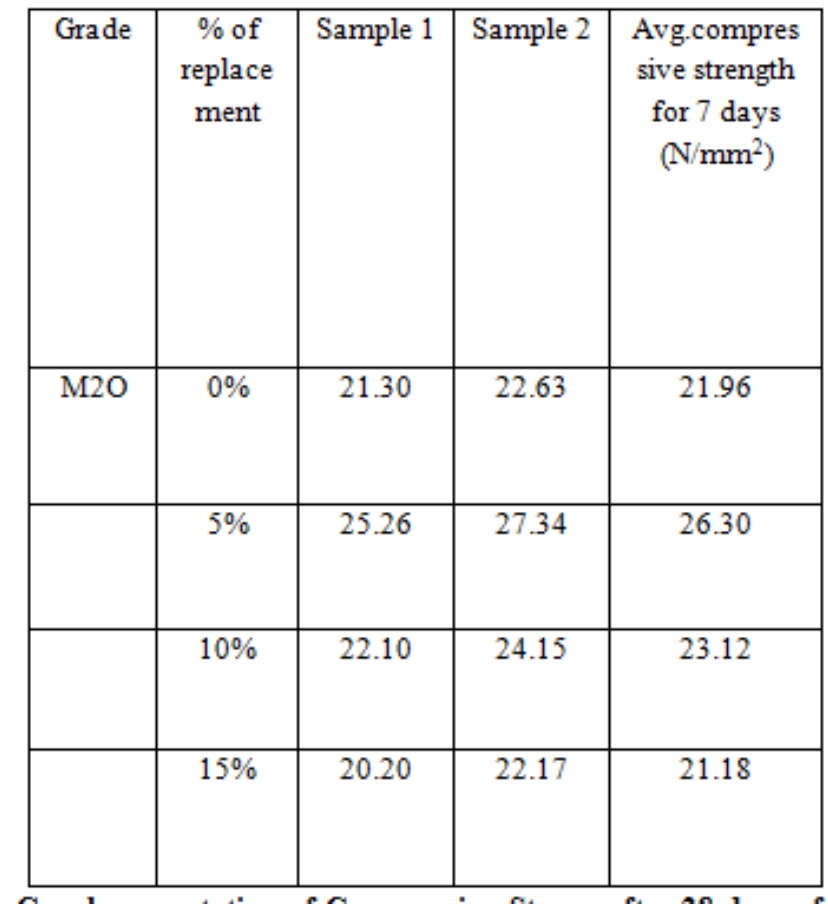

Graph presentation of Compression Stress after 28 days of curing

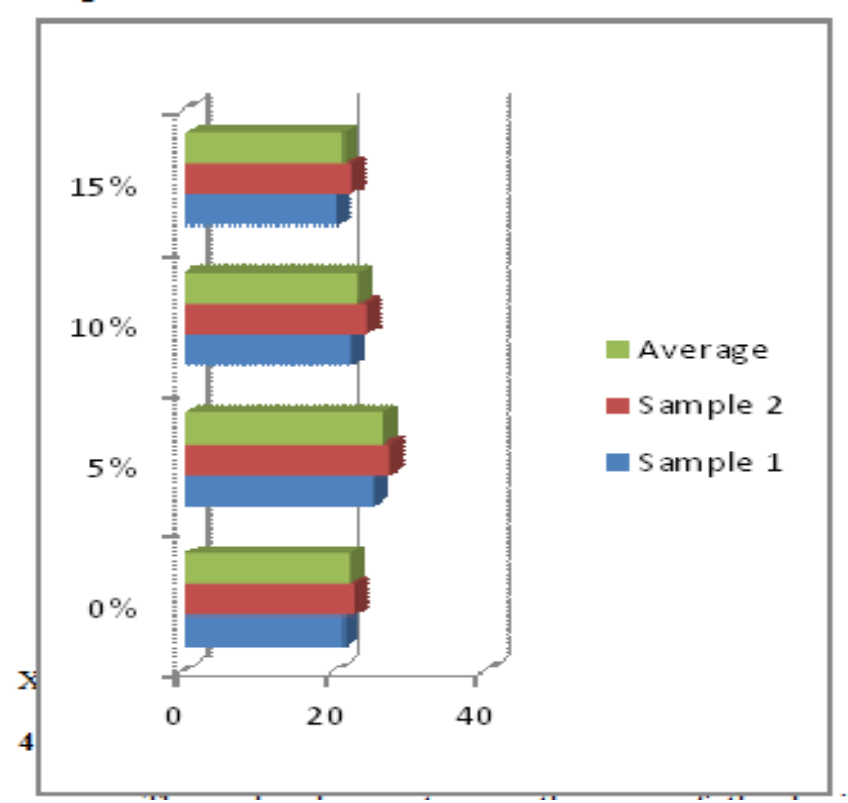

The Unbending Nature Is The One Of The Basic Noteworthy Properties Of Concrete. Split Unbending Nature Test On A Strong Chamber Is The Methodology For Choosing The Flexibility Of Concrete. The Strong Is Weak In Weight On Account Of Its Frail Property And Isn't Required To Contradict The Prompt Strain. The Strong Is Under The Headway Of Breaks When Presented To Pliable Forces. Consequently, It Is Fundamental To Choose The Unbending
Nature Of Concrete As To Choose The Stack At Which The Strong People May Break.[21]-[25]

SP. TENSION STRENGTH ON CUBES FOR 7 DAYS

\begin{tabular}{|c|c|c|c|c|}
\hline Grade & $\begin{array}{c}\% \text { of } \\
\text { replace } \\
\text { ment }\end{array}$ & Sample 1 & $\begin{array}{c}\text { Sampl } \\
\text { e } 2\end{array}$ & $\begin{array}{l}\text { Avg.compres } \\
\text { sive strength } \\
\text { for } 7 \text { days } \\
\left(\mathrm{N} / \mathrm{mm}^{2}\right)\end{array}$ \\
\hline \multirow[t]{4}{*}{$\mathrm{M} 2 \mathrm{O}$} & $0 \%$ & 2.52 & 3.45 & 2.45 \\
\hline & $5 \%$ & 2.71 & 2.45 & 2.98 \\
\hline & $10 \%$ & 1.98 & 1.7 & 1.84 \\
\hline & $15 \%$ & 1.5 & 1.35 & 1.4 \\
\hline
\end{tabular}

Graph Presentation of Sp. Tension Strength of Cylinders after 7 days of curing

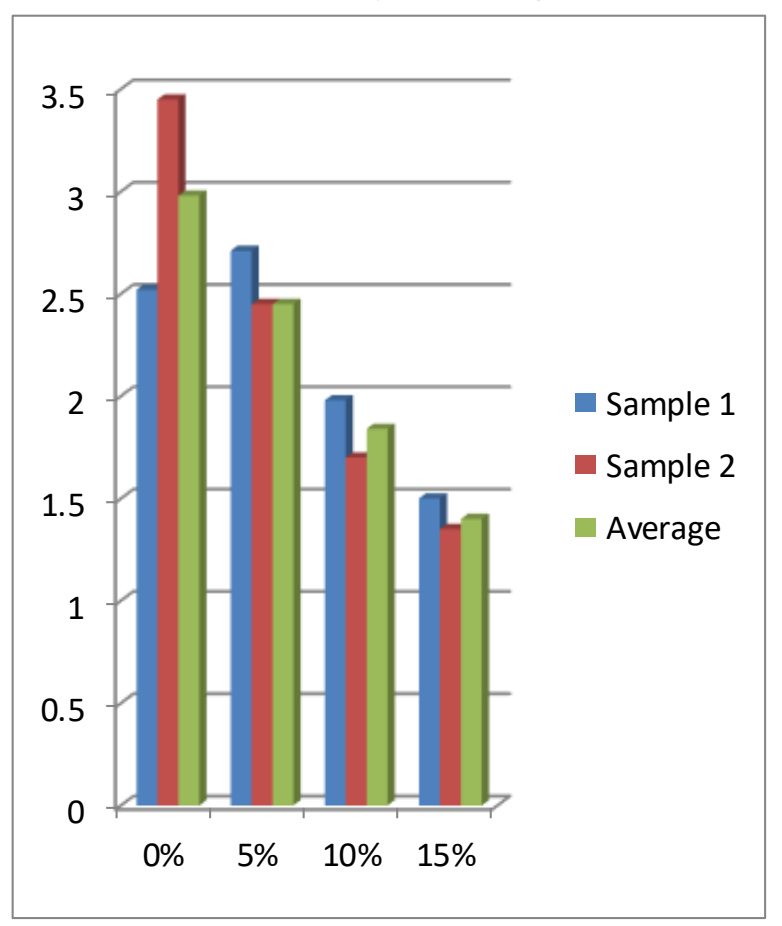

X-axis: percentage replacement of ESP, Y-axis: Sp. Tension strength value.

\section{CONCLUSION}

Egg shell got from city solid wastes is by making powder and included various rates for security substitution and it is settled that the substitution of cement by $5 \%$ egg shell powder is extended by $19.756 \%$ in twenty eight days compression 
strength when stood out from the customary concrete. In like manner it is settled that the substitution of bond by $5 \%$ egg shell powder is extended by $21 \%$ in 7 days split inflexibility when appeared differently in relation to the conventional concretet.

The water binder extent of 0.45 produces medium degree of convenience which is sensible for a huge part of the strong tossing close by. It is seen that there is an improvement of compressive nature of concrete by the development of eggshell powder which is going about as a filler in the strong. Concrete with the extension of $5 \%$ eggshell powder showed the most raised compressive quality. At 28 days assuaging. Correspondingly, concrete with extension of $5 \%$ eggshell powder showed the most raised split unbending nature[26]-[34]

\section{REFERENCES}

1. Iyappan L., Dayakar P., Identification of landslide prone zone for coonoortalukusing spatial technology, International Journal of Applied Engineering Research,V-9,I-22,PP-5724-5732,Y-2014.

2. Kumar J., Sathish Kumar K., Dayakar P.,Effect of microsilica on high strength concrete, International Journal of Applied Engineering Research,V-9,I-22,PP-5427-5432,Y-2014.

3. Dayakar P., Vijay Ruthrapathi G., Prakesh J., Management of bio-medical waste, International Journal of Applied Engineering Research,V-9,I-22,PP-5518-5526,Y-2014

4. Swaminathan N., Dayakar P., Resource optimization in construction project, International Journal of Applied Engineering Research,V-9,I-22,PP-5546-5551,Y-2014.

5. Venkat Raman K., Dayakar P., Raju K.V.B.,An experimental study on effect of cone diameters in penetration test on sandy soil, International Journal of Civil Engineering and Technology,V-8,I-8,PP-1581-1588,Y-2017.

6. Saritha B., Chockalingam M.P.,Photodradation of malachite green DYE using TIO2/activated carbon composite,International Journal of Civil Engineering and Technology,V-8,I-8,PP-156-163,Y-2017

7. Shendge R.B., Chockalingam M.P., Saritha B., Ambica A.,Swat modelling for sediment yield: A case study of Ujjani reservoir in Maharashtra, India,International Journal of Civil Engineering and Technology,V-9,I-1,PP-245-252,Y-2018

8. Chockalingam M.P., Balamurgan V.,Modernisation of an existing urban road-sector in Chennai, a case study report,International Journal of Civil Engineering and Technology,V-8,I-8,PP-1457-1467,Y-2017

9. Saritha B., Chockalingam M.P.,Adsorption study on removal of basic dye by modified coconut shell adsorbent, International Journal of Civil Engineering and Technology,V-8,I-8,PP-1370-1374,Y-2017

10. Saritha B., Chockalingam M.P.,Adsorptive removal of heavy metal chromium from aqueous medium using modified natural adsorbent,International Journal of Civil Engineering and Technology,V-8,I-8,PP-1382-1387,Y-2017

11. Chockalingam M.P., Palanivelraja S.,Retrospective analysis of a theoretical model used for forecasting future air quality near the north Chennai thermal power plant,International Journal of Civil Engineering and Technology,V-8,I-8,PP-1457-1467,Y-2017

12. Saritha B., Chockalingam M.P.,Photodegradation of methylene blue dye in aqueous medium by $\mathrm{Fe}-\mathrm{AC} / \mathrm{TiO} 2$ Composite,Nature Environment and Pollution Technology,V-17,I-4,PP-1259-1265,Y-2018

13. Shendge R.B., Chockalingam M.P., Kaviya B., Ambica A.,Estimates of potential evapotranspiration rates by three methods in upper Bhima Basin, In Maharashtra, India,International Journal of Civil Engineering and Technology,V-9,I-2,PP-475-480,Y-2018

14. Shendge R.B., Chockalingam M.P.,The soil and water assessment tool for Ujjani Reservoir,International Journal of Mechanical Engineering and Technology,V-9,I-2,PP-354-359,Y-2018

15. Shendge R.B., Chockalingam M.P.,A review on soil and water assessment tool,International Journal of Mechanical Engineering and Technology,V-9,I-2,PP-347-353,Y-2018
16. Sachithanandam P., Meikandaan T.P., Srividya T.,Steel framed multi storey residential building analysis and design,International Journal of Applied Engineering Research,V-9,I-22,PP-5527-5529,Y-2014

17. Meikandaan T.P., Ramachandra Murthy A.,Study of damaged RC beams repaired by bonding of CFRP laminates, International Journal of Civil Engineering and Technology,V-8,I-2,PP-470-486,Y-2017

18. Meikandaan T.P., Ramachandra Murthy A.,Retrofittng of reinforced concrete beams using GFRP overlays,International Journal of Civil Engineering and Technology,V-8,I-2,PP-423-439,Y-2017

19. Meikandaan T.P., Ramachandra Murthy A.,Flexural behaviour of RC beam wrapped with GFRP sheets,International Journal of Civil Engineering and Technology,V-8,I-2,PP-452-469,Y-2017

20. Meikandaan T.P., Murthy A.R.,Experimental study on strengthening of rc beams using glass Fiber,International Journal of Civil Engineering and Technology,V-9,I-11,PP-959-965,Y-2018

21. Meikandaan T.P., Hemapriya M.,Use of glass FRP sheets as external flexural reinforcement in RCC Beam,International Journal of Civil Engineering and Technology,V-8,I-8,PP-1485-1501,Y-2017

22. Saraswathy R., Saritha B.,Planning of integrated satellite township at Thirumazhisai,International Journal of Applied Engineering Research,V-9,I-22,PP-5558-5560,Y-2014

23. Saritha B., Ilayaraja K., Eqyaabal Z.,Geo textiles and geo synthetics for soil reinforcement,International Journal of Applied Engineering Research,V-9,I-22,PP-5533-5536,Y-2014

24. Ambica A., Saritha B., Changring G., Singh N B., Rajen M., Salman Md.,Analysis of groundwater quality in and around Tambaram taluk, Kancheepuram district,International Journal of Civil Engineering and Technology,V-8,I-8,PP-1362-1369,Y-2017

25. Arunya A., Sarayu K., Ramachandra Murthy A., Iyer N.R.,Enhancement of durability properties of bioconcrete incorporated with nano silica,International Journal of Civil Engineering and Technology,V-8,I-8,PP-1388-1394,Y-2017

26. Ilayaraja K., Krishnamurthy R.R., Jayaprakash M., Velmurugan P.M., Muthuraj S.,Characterization of the 26 December 2004 tsunami deposits in Andaman Islands (Bay of Bengal, India),Environmental

Earth

Sciences, V-66,I-8,PP-2459-2476,Y-2012

27. Ilayaraja K.,Morphometric parameters of micro watershed in Paravanar sub-basin, Cuddalore District,International Journal of Civil Engineering and Technology,V-8,I-8,PP-1444-1449,Y-2017

28. Ilayaraja K., Singh R.K., Rana N., Chauhan R., Sutradhar N.,Site suitability assessment for residential areas in south Chennai region using remote sensing and GIS techniques,International Journal of Civil Engineering and Technology,V-8,I-8,PP-1468-1475,Y-2017

29. Ilayaraja K., Reza W., Kumar V., Paul S., Chowdhary R.,Estimation of land surface temperature of Chennai metropolitan area using Landsat images,International Journal of Civil Engineering and Technology,V-8,I-8,PP-1450-1456,Y-2017

30. Chitra R.,Experimental study on beam using steel fiber and latex,International Journal of Civil Engineering and Technology,V-8,I-8,PP-1395-1403,Y-2017

31. Chitra R.,Analysis of traffic and management at Kovilambakkam intersection,International Journal of Civil Engineering and Technology,V-8,I-8,PP-1433-1443,Y-2017

32. Aswathy M.,Experimental study on light weight foamed concrete,International Journal of Civil Engineering and Technology,V-8,I-8,PP-1404-1412,Y-2017

33. Aswathy M.,Wastewater treatment using constructed wetland with water lettuce (Eichornia Crasipies),International Journal of Civil Engineering and Technology,V-8,I-8,PP-1413-1421,Y-2017

34. Kiruthiga K., Anandh K.S., Gunasekaran K, Assessment of influencing factors on improving effectiveness and productivity of construction engineers, 2015, International Journal of Applied Engineering Research, V - 10,I -17,p -13849-13854.

\section{AUTHORS PROFILE}

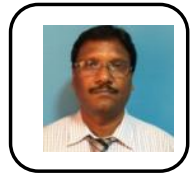

R. Venkata Krishnaiah Asistant Professor, Department Of Civil Engineering,,Bharath Institution of Higher Education And Research,TamilNadu,India 
P. Dayakar, Asistant Professor, Department Of Civil Engineering,,Bharath Institution of Higher Education And Research,TamilNadu, India

K. Venkatraman Professor,,Department Of Civil Engineering,,Bharath Institution Of Higher Education And Research,TamilNadu, India 